\title{
The Application Group Investigation (GI) Learning Model assisted Phet to Facilitate Student Scientific Work Skills
}

\author{
Yhona Arinda $^{1}$, Insih Wilujeng ${ }^{2}$, Heru Kuswanto ${ }^{3}$
}

\section{ARTICLE INFO \\ Article History: \\ Received 18.10.2018 \\ Received in revised form 24.01.2019 \\ Tarih girmek için buray 1 tiklatin. \\ Accepted Available online 01.04.2019}

\begin{abstract}
The study aims to measure the skills of scientific work of students using group investigation model with Phet. This research is a quasi-experimental or quasi-experimental research. Quasi-experimental research is also the development of the true experiment. The research design used is non-equivalent control group design. The researcher was unable to control external variables that influenced the results in this quasi-experimental study. The research design used is non-equivalent control group design. The researcher was unable to control external variables that influenced the results in this quasi-experimental study. The population in this study were all students of X MIA-3 and X MIA-4 on 2nd semester atSMA Negeri 1 Bang untapan in ac ademic year of 2017/2018. Sample selection is by cluster random sampling technique with two classes, where the modeling class is MIA X-3 and X and implementing class is X MIA-4. The results showed that the skills of the scientific work of students who use the model of Cooperative Learning Group Type Group Investigation with Phet in modeling class or implementing class have the same results with good category that are $80.01 \%$ and $77.3 \%$. This suggests that learning to use the model of Group Investigation (GI) with Phet make scientific work skills of learners in the Good category.
\end{abstract}

(C) IJERE. All rights reserved

Keywords:

Learning Model, Group Investigation, Phet, Scientific Working Skills, Students.

\section{INTRODUCTION}

Educators, students, and curriculum are three factors that can make learning meaningful in education (Kauchak and Eggen, 2011). Teaching is a process that is planned and organized by educators for better learning goals of students by choosing a learning model that matches the cont ent of the lesson (Ahmed, 2004). Science and Technology have a major contribution to the development of the country. Thus, improving science learning is a national priority in the education system of a country.

The learning process is a process of communication, namely the delivery of ideas or knowledge from educators to students, such conditions are determined by the role of educators to stimulate students to be actively involved during the learning process in class. Therefore, it takes the role of educators to construct each learning material in order to facilitate students in learning to understand, communicate and perform simulations as the end of learning objectives (Brown and Atkins, 1998).

Physics is a part of science that deals with activities trying to identify the most fundamental principles. Physics has many abstract concepts that students cannot easily understand (Gabeyehu and Gidena, 2017). Engaging students in complex thinking about models and processes is not easy, and traditional learning models may not be suitable for that purpose. Therefore, an educator is required to apply a learning model that is suitable for students.

Education in Indonesia is based on a curriculum that has been developed to realize the goals of national education by taking into an account the development of students, national development needs, and the development of science, technology and art. The Education Unit Level curriculum is a curriculum that is being used by Indonesia. This curriculum requires the existence of scientific work skills that are affirmed in the SKL group of subjects namely conducting experiments, including formulating problems, submitting and testing hypotheses, determining variables, designing and assembling instruments, collecting, processing and interpreting data, drawing conclusions, and communicating the results of experiments verbally and in w riting (KeMenkoPMK, 2015). In line with the objectives of physics subjects in high school, namely to gain experience in applying the scientific method through experiments or experiments, where students test hypotheses by designing experiments through instrument installation, data retrieval, processing and interpretation, and oral and written results of the experiment (Permendiknas, 2006). Therefore, physics learning must be designed to develop students' scientific w ork skills.

\footnotetext{
Corresponding e-mail; yhonaarinda33@gmail.com, https://orcid.org/0000-0003-0132-1204

2; https://orcid.org/0000-0003-1900-7985

3; https://orcid.org/0000-0002-2693-8078

Yogyakarta State University ${ }^{1,2,3}$
} 
Arinda,Y, Wilujeng,I. \& Kuswanto,H. (2019). The application group investigation (GI) learning model assisted phet to facilitate student scientific work skills. International Journal of Educational Research Review,4 (2), 254-261.

A common trend in teaching physics today is the overemphasis on quantitative work (through mathematical calculations). Whereas the main problems in physics are qualitative (understanding of natural behavior). As well as the lack of involvement of students in the learning process that results in the lack of scientific w ork skills possessed by students (Herbar and Druxes, 1986).

The current educational paradigm focuses on preparing students to have readiness to w ork and have the skills to face the challenges of the 21st century. Given the importance of skill development, physics learning must be in accordance with the 21st century education paradigm that provides space for students to devel op skills. Instructional design that suits these needs has the following special characteristics: 1 ) using innovative learning strategies to use modern technology as learning media, 2) integration of cognitive and social abilities with learning content, and 3) giving priority to students' active participation (Anna; Andi; Agus; and Adam, 2017).

The progress of the 21st century requires the development of existing learning models in order to be able to adapt, and be able to foster students' scientific working skills, where 21st century learning emphasizes that educators are able to bring real experience in the learning process (GAP, 2005). One that is suggested is to develop learning concepts that focus on students, where the teacher is only a companion.

Learning models that are expected to be able to overcome the existing problems are cooperative learning models. Cooperative learning in question is Group Investigation (GI) where the Group Investigation (GI) learning model is considered appropriate to be applied in the learning process because it can improve students' scientific w orking skills. Not only that, learning that uses Group Investigation (GI) learning models can also facilitate the limited time provided by the school.

One way to help apply the Group Investigation (GI) learning model to the maximum is to use Phet's help. Phet is an interactive simulation dealing with physical phenomena in the form of research that can be downloaded automatically. The innovation made by researchers in the practice of lea rning innovation is to develop a SSP (Subject Specific Pedagogy) for the Phet assisted Group Investigation (GI) learning model.

Before the practice of learning innovations namely modeling by students and implementation by the teacher was carried out, students first made observations at SMA Negeri 1 Banguntapan as a school where the practice of physics learning innovation. This observation activity aims so that students have a clear picture of the learning process that takes place along with the completeness of facilities and infrastructure that support the learning process at Banguntapan 1 State Senior High School Yogyakarta. Observation results indicate that Banguntapan 1 State Senior High School is one of the high schools that have very adequate learning facilities, but this has not been able to encourage teachers to use the facilities provided to help the learning process to be maximized. The learning model used is still using the learning model in general, which results in students being less active in participating in learning activities.

Classroom learning activities should be carried out actively, inspiring, interesting, challenging and can motivate students to be active in creating creativity and independence of students (Wina and Sanjaya, 2006). Therefore, a learning model is needed that can make students more active in participating in classroom learning activities. Learning systems that require students to be more active in learning and provide opportunities for students to w ork together and solve problems in structured tasks are cooperative learning systems (Anita Lie, 2002).

The lack of learning media is also the cause of the low scientific w ork skills of students at SMA Negeri 1 Banguntapan. This can be seen from the conventional learning process that does not use additional media as a tool for understanding students. Learning media is very important for learning and foster ing scientific work skills in students. Selection of learning media that is in accordance with the material becomes an aspect that must be considered in learning.

One example of learning media that is considered to be able to overcome existing problems is the Physics Education Technology (Phet) virtual simulation. Phet Colorado interactive simulation is an interactive learning media based on discovery (research based) and fun in the form of software and can be used to clarify physical concepts or phenomena that will be explained. This is need for learning models that orient learning in practical activities and discussions that can create the involvement of students in the learning process to foster scientific work skills in students. Students who learn with an active learning model, not only learn better, but also can enjoy the learning process. In this study researchers limit the study population, where the study population used in this study are all students in class X MIA-3 and X MIA-4 SMA Negeri 1 Banguntapan. 
Arinda,Y, Wilujeng,I. \& Kuswanto,H. (2019). The application group investigation (GI) learning model assisted phet to facilitate student scientific work skills. International Journal of Educational Research Review,4 (2), 254-261.

The study aims conducted to analyze the influence of group inquiry type cooperative learning models for students' conceptual knowledge and science process skills in temperature and heat subjects. This research is a quasi-experimental study. The population is all students of class X Medan Exemplary Private High School 2016/2017 academic year. Sample selection is done using random class techniques from two classes. The first class is class X-5 as an experimental class which is taught with the learning model of the cooperative learning type group and the second class is the $\mathrm{X}-4$ class taught through conventional learning. The instrument consists of conceptual science tests and science process skills tests with observation. Data in this study were analyzed using independent $t$-test. The results showed that the conceptual knowledge of students who were taught using the investigative group type learning cooperative model w as better than conventional learning. Science process skills students who are taught using learning model ty pe group investigation are better than conventional learning (Kohl, 2006).

Video analysis, using the Tracker (Open Source Physics) program in the education process introduces new creative methods in teaching physics and making natural science more attractive to students. This way of exploring natural law can amaze students because this illustrative and interactive educational software enables them to think creatively, improve their performance, and help them learn physics. This article discusses improving key competencies in engineering by analyzing real situations of video situations physical problems - by using video analysis and modeling tools using Tracker programs and physical phenomenon simulations from The Physics Education Technology (Phet) Project (VAS method problem tasks). Statistical testing using $\mathrm{t}$-test confirms the significance of differences in the knowledge of experimental and control groups, which are the results of the application of interactive methods (Handayani, 2017).

There are two important elements in learning activities, namely models and learning media used to support ongoing learning activities. These two aspects are interrelated, because in choosing the learning model that will be used will affect the media which will later be used to support the learning model applied. Before choosing and applying a learning model, one teacher must first consider his students, whether students can accept and can easily adapt to the learning model that will be applied. While the selection of learning media can be determined after determining the learning model that is in accordance with the material to be delivered.

The phet assisted investigation group learning model is one of the good mixes, because both make students more active in participating in learning activities. Group learning models can make students more responsible for what they learn, the speed of the learning process can also be arranged by the students themselves. Phet is one of the learning media that can give real examples of the material delivered by the teacher, so that students nolonger get abstract examples, which can make learning more enjoy able and make students more enthusiastic in participating in learning activities (Hachiko, 2015).

\section{METHOD}

This research is a quasi-experimental or quasi-experimental research. Quasi-experimental research is also the development of the true experiment. The research design used is non-equivalent control group design. The researcher was unable to control external variables that influenced the results in this quasi-experimental study.

This research was carried out at SMA Negeri 1 Banguntapan Jl. Ngentak, Baturetno, Banguntapan, Bantul, Yogyakarta City, DIY, 55197, in the even semester of 2017/2018 Academic Year. The population in this study were all students of class X MIA-3 and class X MIA-4. these two classes are taken randomly (cluster random sampling), each class has the same opportunity to be used as a research sample. One class selected to be a modeling class to apply learning model type Investigation Group assisted Phet that was used by the researcher and one other selected class became the implementing class to apply the cooperative learning model type Group investigation assisted Phet that was used by the teacher of physics in X MIA-4 at senior high school Banguntapan. This type of research is quasi experiment research, which is the research aims to find out an influence of learning model type Investigation Group assisted Phet to analyzed the scientific w ork skills of students. 


\section{Material}

The data collection techniques were used an observation sheet to assess the student's scientific working skills. The results of the observation sheet and the learning model were analyzed by calculating the percentage of statement items through the score given based on observation sheet.

\section{Data Analyses}

Before applying the GI learning model, RPP and LKS are designed first so that the implementation of learning can goes well. RPP and LKS students before being used in learning have been validated in advance by experts. Data collection using observation sheets assessing scientific w ork skills carried out by peers in groups. Scientific work skills of students in this study using eight indicators including the skills of students in asking questions, the skills of students in planning experiment experiments, the skills of students in making observations, skills in using tools / materials, skills in identifying experimental results, skills in compile experimental reports, and skills in making conclusions, as well as the skills of students in making presentations. Data analysis techniques using manual calculations with percentage score techniques that can be calculated using the equation:

$$
P R=\frac{\text { Number of KBS sub }- \text { indicators that appear }}{\text { Number of all KBS sub-indicators in } 1 \text { aspect }} \times 100 \%
$$

The interpretation of the emergence of science process skills according to Purwanto (2006) is shown in the following table:

Categories of students' scientific w orking skills in the learning process

\begin{tabular}{|c|c|c|}
\hline No & Persentase & Category \\
\hline 1. & $86 \%-100 \%$ & Very Good \\
\hline 2. & $76 \%-85 \%$ & Good \\
\hline 3. & $60 \%-75 \%$ & Enough \\
\hline 4. & $55 \%-59 \%$ & Deficient \\
\hline 5. & $<54 \%$ & Very Deficient \\
\hline
\end{tabular}

\section{FINDINGS}

\section{a. The Modelling Class}

The scientific work skills of students in the practice of this innovation are measured using an observation sheet assessment by observers. Observation assessment sheets have been validated in advance by experts. Validation results obtained 2.85 with valid categories. Furthermore, if it is valid, the observation sheet can be used in learning. The following observations of students' scientific w ork skills in the learning process are presented in Table 1.

Table 1. Results of Observation Analysis of Scientific Work Skills Modeling Classes

\begin{tabular}{lcc}
\hline Rated Performance & $\begin{array}{c}\text { Average } \\
\text { Score } \\
(\%)\end{array}$ & Category \\
\hline Asking question & 79,68 & Good \\
$\begin{array}{l}\text { Plan an experiment } \\
\text { investigation }\end{array}$ & 80,46 & Good \\
\hline
\end{tabular}




\begin{tabular}{lcl}
\hline Rated Performance & $\begin{array}{c}\text { Average } \\
\text { Score } \\
(\%)\end{array}$ & Category \\
\hline Make observations & 85,00 & Good \\
Using tools / materials & 87,00 & Very good \\
Analyze the results of & 73,00 & Enough \\
the experiment & 78,90 & Good \\
Prepare a trial report & 77,00 & Good \\
Make conclusions & 79,00 & Good \\
Presentation skills & 80,01 & Good \\
Average & & \\
\hline
\end{tabular}

Based on Table 1 above, the average results of the analysis of observations of scientific work skills were $80.01 \%$ in good category. This shows that learning using the Phet assisted Group Investigation (GI) model produces students' scientific work skills in good categories.

\section{b. The Implementation Class}

The scientific work skills of students in the practice of this innovation are measured using an observation sheet assessment by observers. Observer in this implementation class, carried out by 2 observers. Observation sheets are the same in valid modeling and implementation classes. The results of the observation analysis of the scientific working skills of the implementation class students are presented in Table 2 below.

Table 2. Results of Observation Analysis of Working Skills of Scientific Implementation Classes

\begin{tabular}{|c|c|c|}
\hline Rated Performance & $\begin{array}{l}\text { Average } \\
\text { Score }(\%)\end{array}$ & Category \\
\hline Asking question & 81,00 & Good \\
\hline $\begin{array}{l}\text { Plan an experiment / } \\
\text { investigation }\end{array}$ & 81,00 & Good \\
\hline Make observations & 64,70 & Enough \\
\hline Using tools / materials & 64,70 & Enough \\
\hline $\begin{array}{l}\text { Analyze the results of the } \\
\text { experiment }\end{array}$ & 85,30 & Good \\
\hline Prepare a trial report & 82,60 & Good \\
\hline Make conclusions & 81,00 & Good \\
\hline Presentation skills & 78,40 & Good \\
\hline Average & 77,30 & Good \\
\hline
\end{tabular}

Based on Table 2 above, the average results of the analysis of observations of scientific w orking skills obtained $77.3 \%$ in good category. This shows that learning using the Phet assisted Group Investigation (GI) model produces students' scientific work skills in good categories. The results 
Arinda,Y, Wilujeng,I. \& Kuswanto,H. (2019). The application group investigation (GI) learning model assisted phet to facilitate student scientific work skills. International Journal of Educational Research Review,4 (2), 254-261.

showed that the scientific working skills of students who used the Cooperative learning model of the Type of Investigation Group assisted by Phet in the modeling class or in the implementing calss had good categories are $80.01 \%$ and $77.3 \%$. This shows that learning using Phet assisted Group Investigation (GI) models produces students' scientific working skills in good category. Then the results of the observation analysis of the scientific w orking skills of the students in the modeling class are obtained as follows:

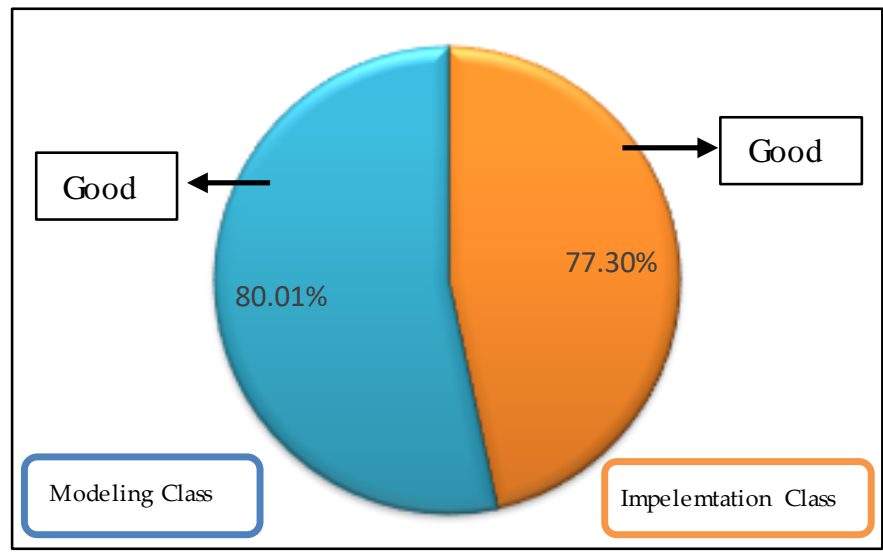

Figure 1. Modeling Class Diagrams and Implementation Classes

\section{RESULT, DISCUSSION, AND SUGGESTIONS}

Group Investigation is a cooperative learning model that is able to make students active in exchanging opinions and discussing in a practicum (Whittaker and Pyne, 2000). The investigation group learning model makes students more active in conducting experiments and in exchanging ideas, the investigation group learning model is a learning model that makes learners learn in small group situations, where students are given responsibility for their own learning, as well as people others who are in the group. The group investigation learning model can develop students' scientific w orking skills (Sisw andi, 2015).

Cooperative learning is a learning model by dividing the grouping system into a small group consisting of 6 students who have different academic backgrounds (heterogeneous). A good type of cooperative learning is could make independent students if the teacher are using the Group Investigation (GI) model (Whittaker and Pyne, 2000). The GI model can direct students regularly to solve physical problems. In addition, the GI learning model can provide enthusiasm for initiative, creative and active. In this model educators begin learning activities by providing a problem that must be solved by students through simple discussion and practicum activities. Through practicum activities, it is expected that there will be an influence on students' scientific w orking skills.

Investigation group learning model has several stages including: 1) grouping (students are divided into several heterogeneous groups), 2) planning (the teacher directs students to choose the topic to be studied), 3) investigation (the teacher conveys the rules in conducting an investigation), 4) organizing (teachers guide students to have discussions), 5) presenting (group leaders convey the results of the discussion), 6) evaluating (the teacher gives explanations and conclusions) (Sharan, 1992).

Physics learning provides a variety of learning experiences to understand the concepts and processes of science, so that it is expected to encourage skilled of students to process science and behave scientifically. The attitude of science can be seen one of them by looking at the students' scientific working skills. Scientific working skills will facilitate students to solving a problem logically and rationally and can improve the ability to analyze information and the truth of a statement that can useful in their daily life (Kholina, 2013).

Physics Education Technology (Phet) is an interactive simulation of physical phenomena that based on free research. With a research approach that combines the results of previous research allows students to link real-life phenomena and underlying science, ultimately deepening understanding and increasing their interest in physics. The results of the study (Perkins, 2006) also show that simulations in Phet are very useful in learning of physics in class. The results of his research show that $62 \%$ of respondents said that it was very useful in learning at class and $22 \%$ of respondents said it wasn't useful. 
Basic of cientific work skills can be done through the provision of experience in the form of independent activities or small groups. One of the activities that can encourage this scientific work skill can be seen by practicum activities. According to (Rukmana, 2014) that said if practicum activities can be used to develop process skills, arouse interest in learning, and provide evidence for the truth of the theory. In addition, practicum activities can also develop students' thinking skills in building concepts of physical material and can provide students with real physics learning experiences and develop scientific work skills both in the classroom and in thelaboratory. Practicum in learning Physics is an effective method to achieve the expected learning goals. Practicum can also make students able to understand the concept and understand the nature of physics as a process and product (Iis, 2013).

Working scientifically is not just collecting facts, gathering theories, or mental processes and manipulative skills. But it is a way of understanding the growing symptoms of nature. And is a product of human desire to imagine. The existence of humans and other living things in nature is very dependent on human behavior in nature. The developed curriculum should consider the matters $r$ aised. In scientific work one needs to be critical, reasoned, and scientific, therefore practicum-based learning is highly recommended to be applied.

One technology that can support learning activities is to use simulations. The simulation media used must be in accordance with existing concepts and theories. One simulation medium that is considered suitable for use in the physics learning process is Physics Education Technology or commonly called Phet. Phet is a simulation media published by the University of Colorado and has been tested for its truth. Phet simulation is a virtual lab that displays a physics animation that $\mathrm{w}$ as abstract to become more real, thus phet simulation can help students to learn in more real situations (Wulandari, 2014). By applying the phetassisted investigation group learning model, it is expected to be able to make students more interested and more active in ongoing learning activities, so that there are no more learning activities that are only focused on the teacher, which results in learning activities not being maximized.

Based on the results of learning innovations and analysis of the findings during modeling and implementing, it was concluded that the average results of scientific work skills in the modeling class after learning to use Phet-assisted Group Investigation (GI) models were in the good category, and the average results of skills scientific work in the implementation class after learning to use the Phet-assisted Group Investigation (GI) model is also in the good category. This shows that learning using the Phet assisted Group Investigation (GI) model produces students' scientific work skills in good categories.

\section{REFERENCES}

Adam, M., Agus, S., Andi, S., \& Anna, P. (2017). Enhancing pre-service physics teachers' creative thinking skills through hot lab design. American Institute Of Physics. https://dx.doi.org/10.1063/1.4995177

Ahmed, R. (2004). Active teaching and its influence on students' academic achievement: The case of grade three. Addis Ababa University.

Atkins, M, \& Brown, G. (1988). Effective teaching in higher education. Methuen \& Co.Ltd.

Druxes \& Herbar. (1986). Kompedium Didaktik Fisika (terjemahan). Bandung: CV. Remaja Karja.

Eggen, P., \& Kauchak, D. (2011). Strategies and models for teachers: Teaching content and thinking skills. British Columbia: Pearson Higher Ed.

Gidena, A., Gebeyehu, D. (2017). The effectiveness of advance organizer model on students' academic achievement in learning work and energy. Interanational Journal of Science Education, 39 (16), 22262242. https://dx.doi.org/10.1080/09500693.2017.1369600

Handayani, S. Parinduri. (2017). The effect of cooperative learning model type group investigation for student's conceptual knowledge and science process skills. IOSR Journal of Research \& Method in Education (IOSR-JRME),8(17),150-155. Doi: 10.9790/7388-0704034954.

Hockicko, dkk. (2015). Development of students' conceptual thinking by means of video analysis and interactive simulations at technical universities. European Journal of Engineering Education, v40 n2 p145-166.

Investigation, A. P. G. (2005). Model Pembelajaran Kooperatif Tipe Gi Group Investigation ), 1-7. 
K. Perkins, W. Adams, M. Dubson, N. Finkelstein, S. Reid, \& C. Wieman. (2006). Phet: Interactive simulations for Teaching and Learning Physics. The Physics Teacher,44,18-23.

KeMenkoPMK. (2015). Indonesia Peringkat ke-57 EDI dari 115 Negara Tahun 2014. (Online). (https://w ww .kemenkopmk.go.id/artikel/indonesiaperingkat-ke-57-edi-dari-115-negara-tahun2014).

Kholina, N. (2013). Penerapan Investigasi Kelompok Bebantan Multimedia Materi Identifikasi Bakteri. Unnes Journal of Biology Education, 2 (1),26-33.

Kohl, P. B., \& Finkelstein, N. D. (2006). Effect of instructional environtment on physics students' representational skills. Physical Review Special Topics - Physics Education Research 2(1). Doi: 10.1103/PhysRevSTPER.2.010102

Lie, A.(2002). Cooperative learning. Grasindo: Jakarta

Permendiknas No.23 Tahun (2006). Standar Kompetensi Lulusan Untuk Satuan Pendidikan Dasar dan Menegah. Jakarta: Menteri Pendidikan Nasional.

Payne,E. \& Whittaker, L. (2000). Developing essential study skills. Pearson Education,Prentice-Hall, England.

Rukmana, Y. D. (2014). Peningkatan Keterampilan Proses Melalui Penerapan Keterampilan Bertanya Pada Pembelajaran IPA Berpusat Pada Siswa Bagi Siswa Kelas V SD Negeri Turi 3 Kecamatan Turi Kabupaten Sleman. Skripsi. Sleman: Universitas Negeri Yogyakarta.

Sanjaya, W. (2006). Pembelajaran Dalam Implementasi Kurikulum Berbasis Kompetensi. Bandung: Kencana.

Sharan, Y. \& Sharan, S. (1992). Expanding cooperative learning through group investigation. New York: Teachers College Press.

Siswandi. (2015). Peningkatan Pemahaman Konsep Kalor dengan Metode Group investigation. Jurnal Praktik Penelitian Tindakan Kelas Pendidikan Dasar dan Menengah, 5(3).

Widiyowati, Iis I., dkk. 2013. The implementation analysis of sels assessment to assess the student of $\mathbf{x}$ senior high school performance in chemistry equilibrium practicum. Jumal Ilmiah. Universitas Mulawarman. ISBN: 978-602-19421-0-9.

Wulandari, dkk. (2014). Penerapan Pembelajaran Berbasis Praktikum Untuk Meningkatkan Keterampilan Proses Sains dan Penguasaan Konsep Siswa Kelas XI IPA 1 di SMA Muhammdiyah 1 Malang. Jurnal Ilmiah. Malang: Universitas Negeri Malang. 